\title{
Radiological Features of IDO1+/PDL1+ Lung Adenocarcinoma: A Retrospective Single-institution Study
}

\author{
KAZUKI TAKADA ${ }^{1}$, GOUJI TOYOKAWA ${ }^{1}$, TETSUZO TAGAWA ${ }^{1}$, \\ MOTOTSUGU SHIMOKAWA ${ }^{2}$, KENICHI KOHASHI ${ }^{3}$, AKIRA HARO ${ }^{1}$, \\ ATSUSHI OSOEGAWA ${ }^{1}$, YOSHINAO ODA ${ }^{3}$ and YOSHIHIKO MAEHARA ${ }^{1}$ \\ Departments of ${ }^{1}$ Surgery and Science, and ${ }^{3}$ Anatomic Pathology, \\ Graduate School of Medical Sciences, Kyushu University, Fukuoka, Japan; \\ ${ }^{2}$ Clinical Research Institute, National Kyushu Cancer Center, Fukuoka, Japan
}

\begin{abstract}
Aim: A combination of immune-checkpoint inhibitors that target the programmed cell death 1 $(P D 1) /$ programmed cell-death ligand 1 (PDL1) pathway and indoleamine 2,3-dioxygenase 1 (IDO1) is a promising treatment for non-small-cell lung cancer. Herein, we investigated clinical features of $I D O 1^{+} / \mathrm{PDLI}^{+}$primary lung adenocarcinoma. Materials and Methods: IDOI and PDLI expression in 388 resected primary lung adenocarcinoma samples was evaluated using immunohistochemistry, and the radiological features of patients with $\mathrm{IDO1}^{+} / \mathrm{PDL1} 1^{+}$lung adenocarcinoma were analyzed. Results: Of 388 specimens, $229(59.0 \%)$ were $I D O 1^{+}, 131$ (33.8\%) were $\mathrm{PDLI}^{+}$, and $109(28.1 \%)$ were $I D O 1^{+} / \mathrm{PDLI}^{+}$. In multivariate analysis, vascular convergence and the absence of surrounding ground glass opacity were significantly associated with IDOI ${ }^{+} / \mathrm{PDLI}^{+}$tumors. Fisher's exact test showed high consolidation/tumor ratio was also significantly associated with $\mathrm{IDOI}^{+} / \mathrm{PDL1}{ }^{+}$tumors. Moreover, maximum standardized uptake in ${ }^{18} \mathrm{~F}$-fluorodeoxyglucose positronemission tomography/computed tomography was significantly higher in patients with $\mathrm{IDOI}^{+} / \mathrm{PDL1} 1^{+}$tumors than in those with $\mathrm{IDO1}^{-}$or PDL1- tumors. Conclusion: IDO1/PDL1 co-expression was significantly related to radiological invasiveness and malignancy in lung adenocarcinoma. This study may help select patients likely to benefit from combination therapy using immunecheckpoint inhibitors.
\end{abstract}

Correspondence to: Kazuki Takada, MD, Ph.D., Department of Surgery and Science, Graduate School of Medical Sciences, Kyushu University, 3-1-1 Maidashi, Higashi-ku, Fukuoka 812-8582, Japan. Tel.: +81 926425466, Fax: +81 926425482, e-mail: k_takada@surg2.med.kyushu-u.ac.jp

Key Words: CT, IDO1, PDL1, lung adenocarcinoma.
Recent immunotherapy advances that target the immune checkpoint factors, programmed cell death-1 (PD1) and programmed cell death-ligand 1 (PDL1), have induced a paradigm shift in the management of non-small-cell lung cancer (NSCLC) (1-6). However, some patients who initially respond to this immunotherapy acquire resistance, and several resistance mechanisms have been reported (7-9). Therefore, combinations of PD1/PDL1 pathway inhibitors with other therapeutic methods, such as chemotherapy, radiation therapy, and other immunotherapy, have been explored to improve response rate and to overcome resistance.

The combination of inhibitors that target indoleamine 2,3dioxygenase-1 (IDO1) and the PD1/PDL1 pathway is a promising new treatment option. IDO1 is a rate-limiting enzyme expressed on antigen-presenting cells and tumor cells which catabolizes tryptophan (an essential amino acid) into a stable metabolite under the kynurenine pathway (10). IDO1 exerts several immunosuppressive effects, such as inducing dysfunction and apoptosis of cytotoxic T-cells, converting naive T-cells into regulatory $\mathrm{T}$-cells, and impairing natural killer T-cell function by depleting tryptophan and generating kynurenine (11, 12); IDO1 inhibitor thus has an antitumor effect.

The combination of inhibitors of IDO1 and PD1/PDL1 is currently attracting much attention. For example, many clinical trials of an IDO1 inhibitor (epacadostat) and a PD1 inhibitor (pembrolizumab) in patients with various types of solid tumor, including NSCLC, are ongoing (13-18). A clinical phase I trial of another combination of IDO1 and PDL1 inhibitors (INCB024360 and atezolizumab, respectively) in previously treated NSCLC is also ongoing (19). Although the clinical features of $\mathrm{IDO}^{+} / \mathrm{PDL}^{+}{ }^{+} \mathrm{NSCLC}$ have not been fully clarified, doing so may provide insights into their optimal use.

We recently investigated the relationship between IDO1 expression in lung adenocarcinoma and patient prognosis and clinicopathological features, including PDL1 expression (20). 
We also evaluated associations between PDL1 expression and clinical features, including computed tomographic (CT) characteristics in 394 patients with primary lung adenocarcinoma (21), and the metabolic characteristics of lung cancer by using ${ }^{18} \mathrm{~F}$-fluorodeoxyglucose positronemission tomography/CT $\left({ }^{18} \mathrm{~F}-\mathrm{FDG} \mathrm{PET} / \mathrm{CT}\right)$ with regard to PDL1 expression (22). In the current study, we analyzed the radiological features of $\mathrm{IDO}^{+} / \mathrm{PDL1}^{+}$lung adenocarcinoma, which may help select patients who are likely to benefit from the combination therapy.

\section{Materials and Methods}

Patients and samples. We retrospectively examined the data for patients who underwent surgical resection of primary lung adenocarcinoma between January 2003 and December 2012 at the Department of Surgery and Science, Graduate School of Medical Sciences, Kyushu University. Previously, we had analyzed the relationships between PDL1 expression and clinical features in 394 patients who had undergone preoperative thin-section CT at our Institution (21). Among them, 388 whose formalin-fixed and paraffin-embedded (FFPE) tumor tissue sections were available for immunohistochemistry (IHC) of IDO1 were enrolled in this study. Their clinicopathological features, including age at surgery, sex, smoking history, pathological tumor-node-metastasis stage (American Joint Committee on Cancer Lung Cancer Staging System, seventh edition) (23), histological subtype (World Health Organization Classification, 2015) (24), and mutation status of epidermal growth factor receptor $(E G F R)$ gene were examined. $E G F R$ status had previously been determined in tumor tissue using the peptide nucleic acid-locked nucleic acid polymerase chain reaction clamp method (Mitsubishi Chemical Medience, Tokyo, Japan) in 230 specimens (25). Clinical information was obtained from medical records. This study was approved by our Institutional Review Board (Kyushu University, IRB No. 29-318).

Chest $C T$. Patients underwent chest $\mathrm{CT}$ in the supine position during inspiratory breath-hold using various multi-detector row scanners: Aquilion 4 (Toshiba), Aquilion 64 (Toshiba), Aquilion One (Toshiba), Aquilion One Vision (Toshiba), Somatom Plus4 Volume Zoom (Siemens), Briliance CT (Phillips), and Briliance iCT (Phillips). The imaging parameters for thin-section CT were tube voltage: 100-500 $\mathrm{mA}$; tube current: $120 \mathrm{kVp}$; scan field of view: $320-360 \mathrm{~mm}$; slice thickness: $2 \mathrm{~mm}$. Real-time exposure control (Toshiba) or automatic exposure control (Siemens and Phillips) was added in each study. All of the CT data sets were transferred to a Picture Archiving and Communication System, which was accessible at workstations (Volume Analyzer, Synapse-Vincent; Fujifilm, Tokyo, Japan) with a specialized application for lungs. The consolidation diameter of each tumor $(\mathrm{C})$ and the diameter of the whole tumor $(\mathrm{T})$ including ground glass opacity (GGO) were measured manually with axial 2dimensional $\mathrm{CT}$ data at 2-mm sections; the $\mathrm{C} / \mathrm{T}$ ratio was then calculated. Three thoracic oncologists evaluated all CT images; if their independent assessments did not agree, the CT images were reviewed together to achieve consensus judgments, which were adopted as final results.

${ }^{18}$ F-FDG PET/CT. ${ }^{18} \mathrm{~F}$-FDG PET/CT was performed using various scanners: Secat Exact HR+ (Siemens), Biograph mCT (Siemens),
Table I. Clinicopathological characteristics of all patients.

\begin{tabular}{lc}
\hline Factors & Value \\
\hline Age, years & \\
Median (range) & $69(29-85)$ \\
Gender, $\mathrm{n}$ & \\
Male & 193 \\
Female & 195 \\
Smoking status, $\mathrm{n}$ & \\
Never-smoker & 197 \\
Smoker & 191 \\
Pathological stage, $\mathrm{n}$ & \\
IA & 210 \\
IB & 72 \\
IIA & 32 \\
IIB & 28 \\
IIIA & 36 \\
IIIB & 5 \\
IV & 5 \\
Histological subtype, $\mathrm{n}$ & \\
AAH/AIS/MIA & 38 \\
Lepidic predominant & 24 \\
Papillary predominant & 288 \\
Acinar predominant & 6 \\
Micropapillary predominant & 1 \\
Solid predominant & 25 \\
Variants & 6 \\
EGFR, $\mathrm{n} *$ & \\
Wild-type & 119 \\
Mutant & 111 \\
IDO1, $\mathrm{n}$ & \\
Negative & 159 \\
Positive & 229 \\
PDL1, $\mathrm{n}$ & \\
Negative & \\
Positive & \\
IDO1/PDL1, $\mathrm{n}$ & \\
Other & \\
Co-expression & \\
\hline & \\
\hline
\end{tabular}

AAH: Atypical adenomatous hyperplasia; AIS: adenocarcinoma in situ; EGFR: epidermal growth factor receptor gene; IDO1: indoleamine 2,3dioxygenase 1; MIA: minimally invasive adenocarcinoma; PDL1: programmed cell-death ligand $1 .{ }^{*}$ Cases for which data were available.

Discovery STElite16 (General Electric Healthcare, Milwaukee, WI, USA). Each tumor's maximum standardized uptake value $\left(\mathrm{SUV}_{\max }\right)$ was evaluated, and statistically analyzed.

IHC analysis. FFPE tumor-tissue sections were used to determine IHC expression of IDO1 and PDL1 in primary lung adenocarcinomas. IHC analysis was conducted using commercially available antibodies against IDO1 at 1:200 dilution (mouse monoclonal, clone UMAB126; Origene Technologies, Rockville, MD, USA), and PDL1 at 1:100 dilution (rabbit monoclonal, clone SP142; Spring Bioscience, Ventana, Tucson, AZ, USA). IHC staining for PDL1 was performed as previously described (26). IHC staining for IDO1 was performed as follows: $4-\mu \mathrm{m}$ sections were cut, dewaxed with xylene, and rehydrated through an ethanol 
A

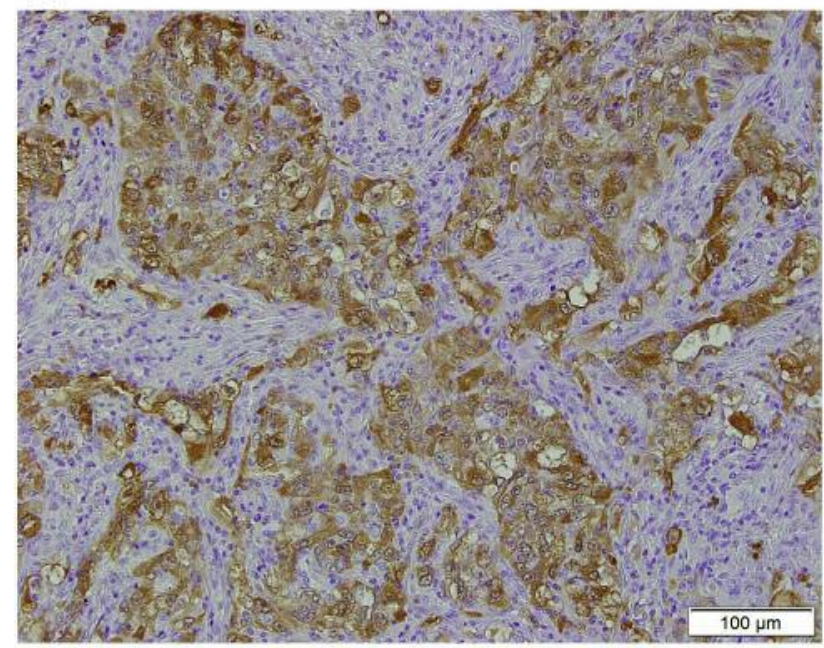

B

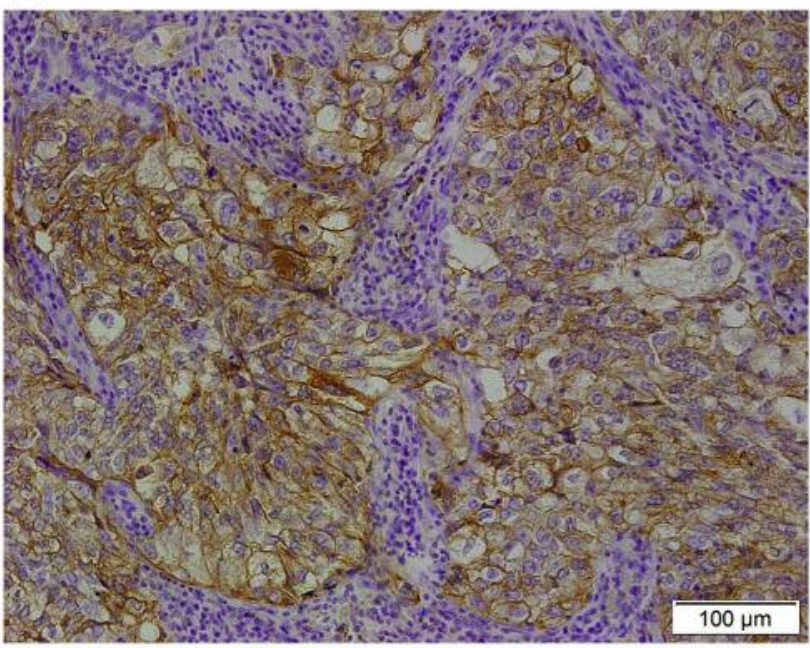

Figure 1. Representative images of immunohistochemical staining for indoleamine 2,3-dioxygenase 1 (IDO1) (A) and programmed cell-death ligand $1(P D L 1)(B)$ in surgically resected specimens from patients with primary lung adenocarcinoma. A: Positive cytoplasmic and membranous staining for IDO1. B: Positive membranous staining for PDL1. Scale bar $=100 \mu \mathrm{m}$.

gradient. After inhibiting endogenous peroxidase activity for $30 \mathrm{~min}$ with $3 \% \mathrm{H}_{2} \mathrm{O}_{2}$ in methanol, sections were pretreated with EDTA $(\mathrm{pH} 8.0)$ in a decloaking chamber at $110^{\circ} \mathrm{C}$ for $15 \mathrm{~min}$, and then incubated with monoclonal antibodies at $4{ }^{\circ} \mathrm{C}$ overnight. The immune complex was detected with a Dako EnVision Detection System (Dako, Glostrup, Denmark). The sections were finally reacted in 3,3'-diaminobenzidine, counterstained with hematoxylin, and mounted. Sections from human placentas were used as positive controls for IDO1.

The tumor proportion score (TPS) was independently estimated as the proportion of positively stained cells as a percentage that of total carcinoma cells in whole sections by three investigators (KT, $\mathrm{KK}$, and $\mathrm{YK}$ ) who were blinded to patients' clinical status. Final scores were decided by consensus. IHC evaluation for PDL1 was conducted as previously described (26); samples with less than $1 \%$ tumor (membranous) staining were considered negative in this study. For IDO1, cytoplasmic and membranous immunostaining on tumor cells was quantified; a cut-off value at $1 \%$ was set in this study, with reference to a previous report (27).

Statistical analysis. Associations between co-expression of IDO1/PDL1 and patient characteristics or C/T ratios were analyzed using Fisher's exact test. Univariate and multivariate analyses of relationships between IDO1/PDL1 co-expression and CT features, such as vascular convergence, surrounding GGO, air bronchogram, notching, pleural indentation, spiculation, and cavitation, were performed by logistic regression analysis with the backward elimination method. The association between IDO1/PDL1 coexpression and $\mathrm{SUV}_{\max }$ in preoperative ${ }^{18} \mathrm{~F}$-FDG $\mathrm{PET} / \mathrm{CT}$ was examined using Student's $t$-test. All statistical analyses were performed using JMP Statistical Discovery Software (version 11.0; SAS Institute, Cary, NC, USA). Values of $p<0.05$ were considered significant.

\section{Results}

$\mathrm{IDOI}^{+} / \mathrm{PDL} 1^{+}$lung adenocarcinoma and patient clinicopathological characteristics. Of the 388 patients in the present study, 193 (49.7\%) were male; 197 (50.8\%) had never smoked; their median age was 69 years (range $=29-85$ years; Table I). Of the 230 patients for whom EGFR status was available, 119 (51.7\%) had wild-type EGFR, and 111 (48.3\%) had mutant EGFR.

IHC staining for IDO1 was detected in cytoplasm and membrane, and that for PDL1 was detected on cancer-cell membranes (Figure 1). Of the 388 specimens, 229 (59.0\%) were $\mathrm{IDO}^{+}, 131$ (33.8\%) were $\mathrm{PDL}^{+}$, and $109(28.1 \%)$ were $\mathrm{IDO}^{+} / \mathrm{PDL}^{+}$. IDO1/PDL1 co-expression was significantly associated with male sex, smoking history, advanced-stage disease, predominantly micropapillary or solid histological subtypes, and wild-type EGFR (Fisher's exact test; Table II).

IDO1/PDL1 co-expression and CT features in primary lung adenocarcinoma. Figure 2 shows representative images of CT features, vascular convergence, surrounding GGO, air bronchogram, notching, pleural indentation, spiculation, and cavitation. Among the 388 patients, vascular convergence was found in $262(67.5 \%)$, surrounding GGO in 188 (48.4\%), air bronchogram in $308(79.4 \%)$, notching in 139 $(35.8 \%)$, pleural indentation in $306(78.9 \%)$, spiculation in $175(45.1 \%)$, and cavitation in 73 (18.8\%; Table III). In univariate analysis, IDO1/PDL1 co-expression was 
A

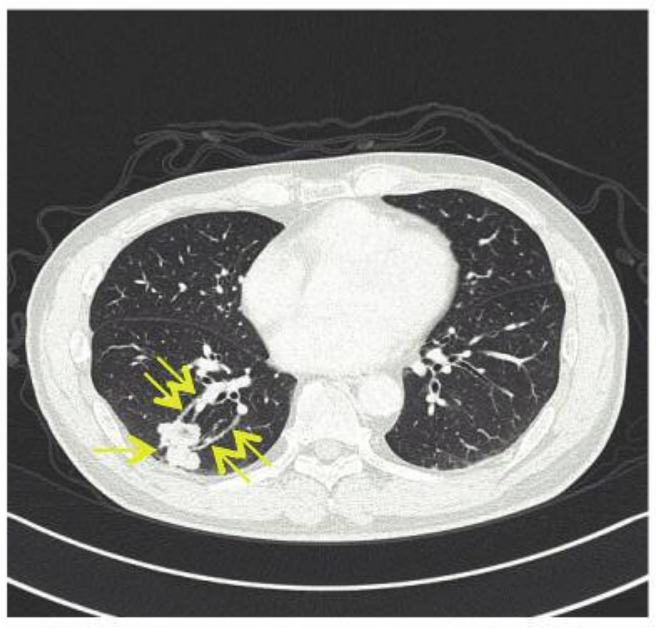

C

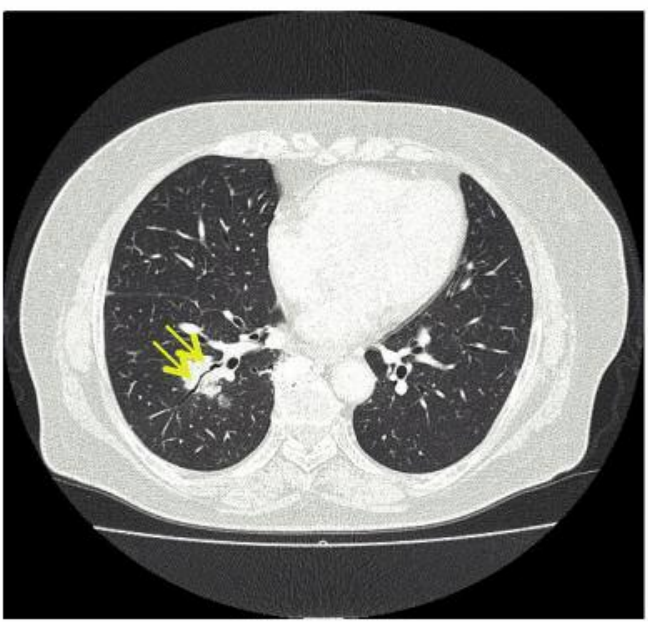

$\mathrm{E}$

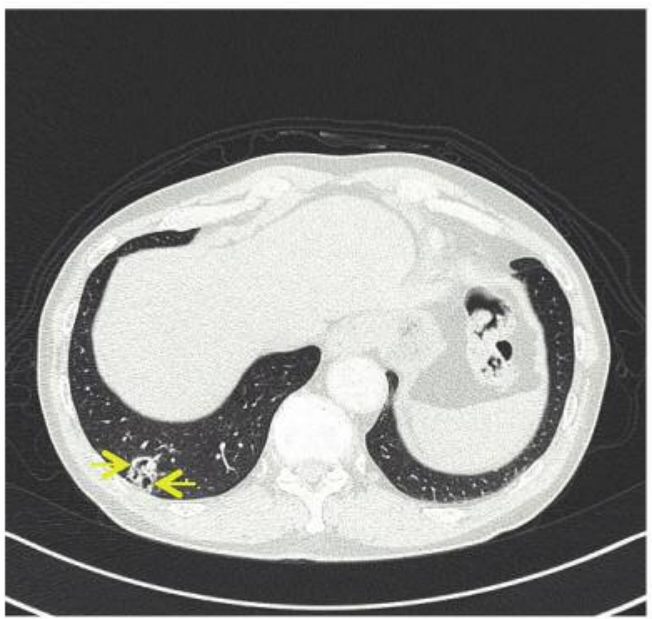

B

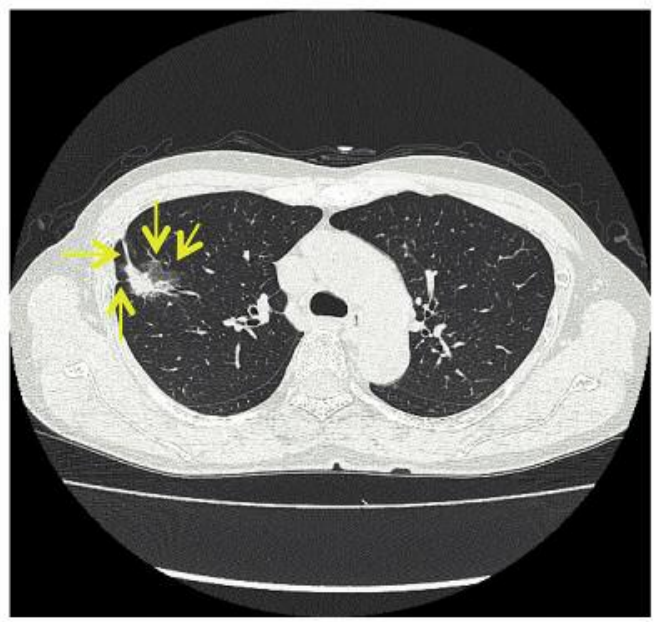

D

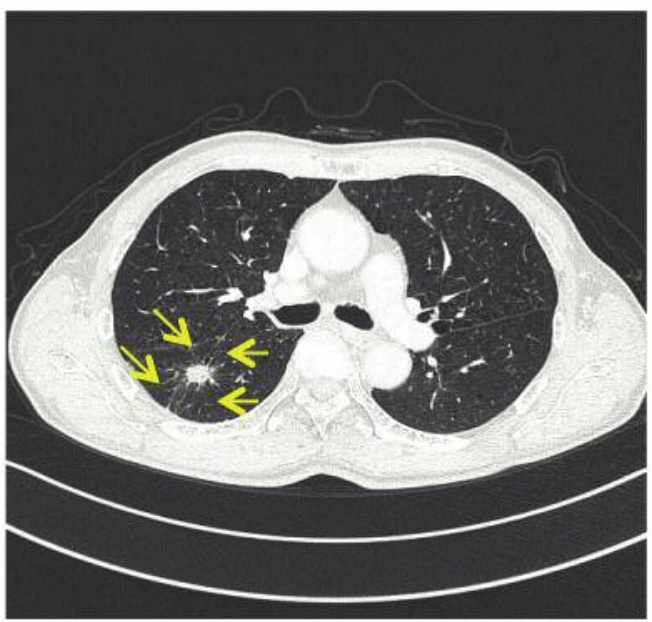

Figure 2. Representative images showing computed tomographic features in patients with primary lung adenocarcinoma. A: Vascular convergence and notching. B: Surrounding ground glass opacity and pleural indentation. C: Air bronchogram. D: Spiculation. E: Cavitation. 


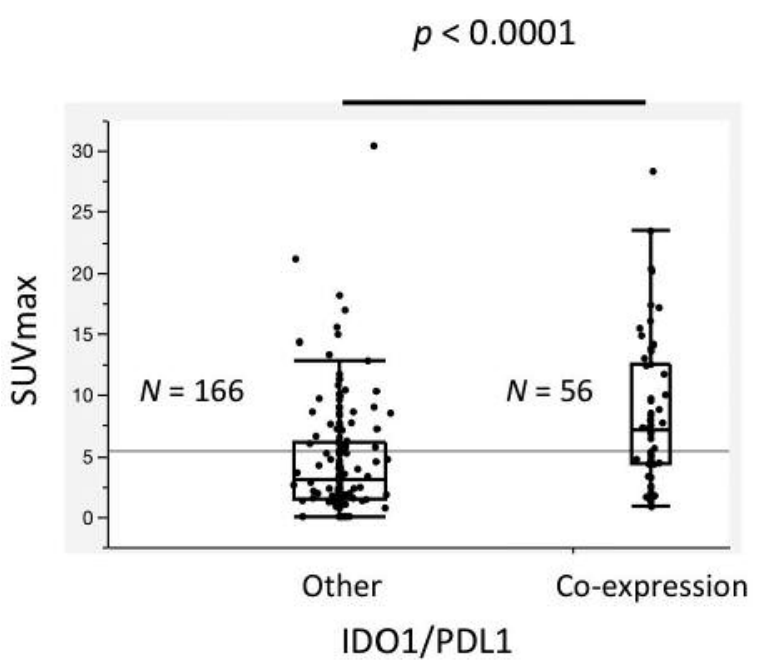

Figure 3. Maximum standardized uptake value (SUVmax) in ${ }^{18} \mathrm{~F}$ fluorodeoxyglucose positron-emission tomography/computed tomography according to "Indoleamine 2,3-dioxygenase 1 (IDO1)/programmed celldeath ligand 1 (PDL1) co-expression. $S U V_{\text {max }}$ was significantly higher in patients with $I D O 1^{+} / P D L 1^{+}$specimens than those with $I D O 1^{-}$or PDL1- specimens $(p<0.0001)$. Data are presented as box-and-whisker plots. The box spans the interquartile range, the median is indicated by a line inside the box, and the upper and lower whiskers indicate the third quartile plus $1.5 \times I Q R$ and the first quartile minus $1.5 \times I Q R$.

significantly associated with the presence of vascular convergence, notching, spiculation, and cavitation, and the absence of surrounding GGO and air bronchogram. In multivariate analysis, the presence of vascular convergence and the absence of surrounding GGO were significantly associated with IDO1/PDL1 co-expression (Table III).

$\mathrm{IDO}^{+} / \mathrm{PDL1}^{+}$expression was positively associated with $\mathrm{C} / \mathrm{T}$ ratio $(p=0.0002$; Table IV).

$\mathrm{IDOI}^{+} / \mathrm{PDL1} 1^{+}$expression and ${ }^{18} \mathrm{~F}-\mathrm{FDG}$ PET/CT results in primary lung adenocarcinoma. The metabolic characteristics of primary lung adenocarcinoma were evaluated using $18 \mathrm{~F}$ FDG PET/CT, an essential imaging modality in lung cancer diagnosis and staging, with regard to IDO1/PDL1 coexpression in 222 patients for whom data were available. The average $\mathrm{SUV}_{\max }$ of patients with $\mathrm{IDO}^{+} / \mathrm{PDL}^{+}$tumors $(8.41$; range $=0.80-28.3)$ was significantly higher than that of patients with $\mathrm{IDO}^{-}$or $\mathrm{PDL}^{-}$tumors $(4.45$; range $=0.00$ $30.4 ; p<0.0001$; Figure 3).

\section{Discussion}

In the present study, we examined the relationships between IDO1/PDL1 co-expression and features of chest CT and ${ }^{18} \mathrm{~F}$ FDG PET/CT in patients with primary lung adenocarcinoma.
Table II. Association between indoleamine 2,3-dioxygenase 1 (IDO1)/ programmed cell-death ligand 1 (PDL1) expression and clinicopathological factors.

\begin{tabular}{|c|c|c|c|c|}
\hline \multirow[t]{2}{*}{ Factor } & \multirow[t]{2}{*}{$\mathrm{N}(\%)$} & \multicolumn{2}{|c|}{ IDO1/PDL1, N (\%) } & \multirow[t]{2}{*}{$p$-Value } \\
\hline & & Other & Co-expression & \\
\hline \multicolumn{5}{|l|}{ Age } \\
\hline$<70$ Years & $205(52.8)$ & $148(53.1)$ & $57(52.3)$ & 0.9103 \\
\hline$\geq 7$ Years & $183(47.2)$ & $131(46.9)$ & $52(47.7)$ & \\
\hline \multicolumn{5}{|l|}{ Gender } \\
\hline Male & $193(49.7)$ & $129(46.2)$ & $64(58.7)$ & 0.0318 \\
\hline Female & $195(50.3)$ & $150(53.8)$ & $45(41.3)$ & \\
\hline \multicolumn{5}{|l|}{ Smoking status } \\
\hline Never-smoker & $197(50.8)$ & $155(55.6)$ & $42(38.5)$ & 0.0032 \\
\hline Smoker & $191(49.2)$ & $124(44.4)$ & $67(61.5)$ & \\
\hline \multicolumn{5}{|l|}{$\begin{array}{l}\text { Radiological } \\
\text { tumor diameter }\end{array}$} \\
\hline$\leq 2.0 \mathrm{~cm}$ & $176(45.4)$ & $133(47.7)$ & $43(39.5)$ & 0.1733 \\
\hline$>2.0 \mathrm{~cm}$ & $212(54.6)$ & $146(52.3)$ & $66(60.5)$ & \\
\hline \multicolumn{5}{|l|}{ Pathological stage } \\
\hline I & $282(72.7)$ & $214(76.7)$ & $68(62.4)$ & 0.0054 \\
\hline$\geq \mathrm{II}$ & $106(27.3)$ & $65(23.3)$ & $41(37.6)$ & \\
\hline \multicolumn{5}{|l|}{ Histological subtype } \\
\hline Micropapillary/solid & $26(6.7)$ & $8(2.9)$ & $18(16.5)$ & $<0.0001$ \\
\hline Other & $362(93.3)$ & $271(97.1)$ & $91(83.5)$ & \\
\hline \multicolumn{5}{|l|}{$E G F R^{*}$} \\
\hline Wild-type & $119(51.7)$ & $81(46.0)$ & $38(70.4)$ & 0.0019 \\
\hline Mutant & $111(48.3)$ & $95(54.0)$ & $16(29.6)$ & \\
\hline
\end{tabular}

EGFR: Epidermal growth factor receptor gene. *Cases for which data were available.

The results of this study were similar to those of our previous reports on PDL1 expression $(21,22,28)$. Moreover, both radiological and clinicopathological features of $\mathrm{IDO}^{+} / \mathrm{PDL}^{+}$lung adenocarcinoma were similar to those of $\mathrm{PDL}^{+}{ }^{+}$lung adenocarcinoma in accordance with our previous reports $(21,26)$. We recently showed that IDO1 expression was significantly associated with PDL1 expression in primary lung adenocarcinoma; all patients in an earlier study cohort with strong PDL1 expression (PDL1 TPS $\geq 50 \%$ ) were positive for IDO1 (20). Expression of both IDO1 and PDL1 increases through responses to interferon- $\gamma$ and transforming growth factor $\beta$ released in the tumor microenvironment, and immunotherapies that target these proteins might be effective against T-cell-inflamed tumors (19). Therefore, the relationship between IDO1/PDL1 coexpression and the infiltration by immune-related cells such as $\mathrm{CD}^{+}, \mathrm{CD}^{+}$, and $\mathrm{CD}^{+}$cells should be examined in future studies in order to confirm the above points. Our present results indicate that the combination of inhibitors against IDO1 and the PD1/PDL1 pathway might be more effective against non-squamous cell cancer with no EGFR mutation, in patients with smoking history, which is expected 
Table III. Univariate and multivariate analyses for relationships between indoleamine 2,3-dioxygenase 1 (IDO1)/programmed cell-death ligand 1 (PDL1) expression and computed tomographic (CT) features.

\begin{tabular}{|c|c|c|c|c|c|c|c|c|c|c|}
\hline \multirow[t]{2}{*}{ CT feature } & & \multirow[t]{2}{*}{$\mathrm{N}(\%)$} & \multicolumn{2}{|c|}{ IDO1/PDL1, N (\%) } & \multicolumn{3}{|c|}{ Univariate analysis } & \multicolumn{3}{|c|}{ Multivariate analysis } \\
\hline & & & Other & Co-expression & OR & $95 \% \mathrm{CI}$ & $p$-Value & OR & $95 \% \mathrm{CI}$ & $p$-Value \\
\hline \multirow[t]{2}{*}{ Vascular convergence } & Absent & $126(32.5)$ & $111(39.8)$ & $15(13.8)$ & 1.00 & & & 1.00 & & \\
\hline & Present & $262(67.5)$ & $168(60.2)$ & $94(86.2)$ & 4.14 & $2.34-7.77$ & $<0.0001$ & 2.10 & $1.10-4.18$ & 0.0251 \\
\hline \multirow[t]{2}{*}{ Surrounding GGO } & Absent & $200(51.6)$ & $114(40.9)$ & $86(78.9)$ & 1.00 & & & 1.00 & & \\
\hline & Present & $188(48.4)$ & $165(59.1)$ & $23(21.1)$ & 0.18 & $0.11-0.31$ & $<0.0001$ & 0.25 & $0.14-0.43$ & $<0.0001$ \\
\hline \multirow[t]{2}{*}{ Air bronchogram } & Absent & $80(20.6)$ & $49(17.6)$ & $31(28.4)$ & 1.00 & & & & & \\
\hline & Present & $308(79.4)$ & $230(82.4)$ & $78(71.6)$ & 0.54 & $0.32-0.91$ & 0.0200 & & & \\
\hline \multirow[t]{2}{*}{ Notching } & Absent & $249(64.2)$ & $193(69.2)$ & $56(51.4)$ & 1.00 & & & & & \\
\hline & Present & $139(35.8)$ & $86(30.8)$ & $53(48.6)$ & 2.12 & $1.35-3.35$ & 0.0011 & & & \\
\hline \multirow[t]{2}{*}{ Pleural indentation } & Absent & $82(21.1)$ & $64(22.9)$ & $18(16.5)$ & 1.00 & & & & & \\
\hline & Present & $306(78.9)$ & $215(77.1)$ & $91(83.5)$ & 1.50 & $0.86-2.74$ & 0.1557 & & & \\
\hline \multirow[t]{2}{*}{ Spiculation } & Absent & $213(54.9)$ & $171(61.3)$ & $42(38.5)$ & 1.00 & & & & & \\
\hline & Present & $175(45.1)$ & $108(38.7)$ & $67(61.5)$ & 2.53 & $1.61-4.00$ & $<0.0001$ & & & \\
\hline \multirow[t]{2}{*}{ Cavitation } & Absent & $315(81.2)$ & $236(84.6)$ & $79(72.5)$ & 1.00 & & & & & \\
\hline & Present & 73 (18.8) & $43(15.4)$ & $30(27.5)$ & 2.08 & $1.22-3.54$ & 0.0076 & & & \\
\hline
\end{tabular}

CI: Confidence interval; GGO: ground glass opacity; OR: odds ratio.

to show greater sensitivity to anti-PD1/PDL1 treatment than to monotherapy with PD1/PDL1 inhibitors $(1-4,6)$.

Vascular convergence of surrounding structures on chest CT is a sign of malignancy, and is considered to reflect fibrosis in the tumor; surrounding GGO in tumors, especially adenocarcinomas, indicates a replacement growth pattern of alveolar-lining cells (29). A predominant GGO patterns suggest tumor noninvasiveness, as the Japan Clinical Oncology Group 0201 study defined tumors with a $\mathrm{C} / \mathrm{T}$ ratio $\leq 0.25$ on thin-section $\mathrm{CT}$ as being radiologically noninvasive lung adenocarcinoma, since such tumors correspond well to pathologically noninvasive adenocarcinomas with very high sensitivity (30). We recently reported that the presence of vascular convergence, the absence of surrounding GGO, and a high $\mathrm{C} / \mathrm{T}$ ratio were significantly associated with $\mathrm{PDL} 1^{+}$ lung adenocarcinoma, which was likely to be radiologically invasive and malignant $(21,28)$. In this study, $\mathrm{IDO}^{+} / \mathrm{PDL}^{+}$ lung adenocarcinoma was also significantly associated with the presence of vascular convergence, absence of surrounding GGO, and high $\mathrm{C} / \mathrm{T}$ ratio. Therefore, $\mathrm{IDO}^{+} / \mathrm{PDL}^{+}{ }^{+}$lung adenocarcinoma may also be radiologically invasive and malignant, similarly to $\mathrm{PDL1}^{+}$lung adenocarcinoma. Moreover, IDO $1^{+} / \mathrm{PDL}^{+}{ }^{+}$lung adenocarcinomas had higher $\mathrm{SUV}_{\max }$ in ${ }^{18} \mathrm{~F}-\mathrm{FDG} \mathrm{PET} / \mathrm{CT}$ than $\mathrm{IDO}^{-}$and $\mathrm{PDL}^{-}$ tumors, which indicates that IDO1/PDL1 co-expression is related to malignant features associated with high glucose metabolism, similarly to PDL1 expression (22).

We also examined the association between IDO1/PDL1 co-expression and clinicopathological features including age at surgery, sex, smoking history, pathological tumor-node-
Table IV. Indoleamine 2,3-dioxygenase 1 (IDO1)/programmed celldeath ligand 1 (PDL1) expression according to consolidation diameter/tumor diameter $(C / T)$ ratio on computed tomography.

\begin{tabular}{lccc}
\hline C/T ratio & \multicolumn{2}{c}{ IDO1/PDL1, N $(\%)$} & \multirow{2}{*}{$p$-Value } \\
\cline { 2 - 3 } & Other & Co-expression & \\
\hline 0 (Pure GGO) & $33(11.8)$ & $6(5.5)$ & 0.0002 \\
$0.10-0.25$ & $19(6.8)$ & $1(0.9)$ & \\
$0.26-0.50$ & $43(15.4)$ & $7(6.4)$ & \\
$\geq 0.51$ & $184(66.0)$ & $95(87.2)$ & \\
\hline
\end{tabular}

GGO: Ground glass opacity.

metastasis stage, histological subtype, and EGFR mutation status. In this study, IDO1/PDL1 co-expression was significantly associated with male sex, smoking history, advanced-stage disease, predominantly micropapillary or solid histological subtypes, and wild-type EGFR. Our previous reports showed that PDL1 expression was also significantly associated with these factors in lung adenocarcinoma $(21,26)$. These data suggest that both $\mathrm{PDL}^{+}{ }^{+}$and $\mathrm{IDO}^{+} / \mathrm{PDL}^{+}$lung adenocarcinomas are pathologically invasive and malignant, and imply that clinical features of $\mathrm{IDO}^{+} / \mathrm{PDL}^{+}$lung adenocarcinoma are similar to those of $\mathrm{PDL}^{+}$lung adenocarcinoma in both clinicopathological and radiological features.

There are several limitations associated with the present study. Firstly, this was a retrospective single-institution study 
and not a trial-based correlative study; however, 388 patients were examined for associations between IDO1/PDL1 coexpression, for the features of two imaging modalities, chest $\mathrm{CT}$ and ${ }^{18} \mathrm{~F}-\mathrm{FDG}$ PET/CT, in addition to their clinicopathological characteristics. The data obtained might help identify patients who would benefit from combination therapies that target IDO1 and the PD1/PDL1 pathway. Validation cohort studies should be conducted to confirm our findings. Secondly, we conducted PDL1 IHC using only one antibody, SP142, which was used in clinical trials on atezolizumab $(1,4)$. Some recent studies showed that the positivity rate of PDL1 expression using SP142 was lower than that for other antibodies, such as 28-8, 22C3, and SP263 (3133). However, a clinical phase I trial on combination therapy using the IDO1 inhibitor INCB024360, and the PDL1 inhibitor atezolizumab, in previously treated NSCLC is ongoing (19). This present study may be a useful reference in understanding the results of that clinical trial. PDL1 expression should be evaluated using other antibodies, such as $22 \mathrm{C} 3$, as used in the ongoing clinical trials with the combination therapy of IDO1 inhibitor epacadostat, and PD1 inhibitor pembrolizumab, in patients with various types of solid tumors, including NSCLC (13-18). Thirdly, no definitive guidelines for antibody use or quantification of IDO1 expression in NSCLC exist, and no comparative data for different IDO1 antibodies are available. We used clone UMAB126 and set the cut-off value for positivity at $1 \%$ staining of tumor-cell cytoplasm and membrane in this study. However, this antibody has not been evaluated in a clinical setting. Therefore, IDO1 expression should be further evaluated using other antibodies and cut-off values. The fourth limitation is the lack of analysis for advanced, late-stage disease because we examined associations between IDO1/PDL1 co-expression and clinical features using surgical specimens. An analysis of advanced cases is warranted to validate our findings here.

To our knowledge, this is the first report to demonstrate a relationship between IDO1/PDL1 co-expression and clinicopathological characteristics, including features of imaging modalities in resected lung adenocarcinomas. We found IDO1/PDL1 co-expression to be associated with radiological invasiveness and malignancy in lung adenocarcinoma. This study may be a useful reference in selecting patients who are likely to benefit from combined IDO1/PDL1 inhibitor therapy.

\section{Funding}

This work was not supported by any funding sources.

\section{Acknowledgements}

The Authors thank Marla Brunker, from Liwen Bianji, Edanz Group China (www.liwenbianji.cn/ac), for editing the English text of a draft of this article.

\section{Conflicts of Interest}

The Authors have no conflict of interest in regard to this study.

\section{References}

1 Rittmeyer A, Barlesi F, Waterkamp D, Park K, Ciardiello F, von Pawel J, Gadgeel SM, Hida T, Kowalski DM, Dols MC, Cortinovis DL, Leach J, Polikoff J, Barrios C, Kabbinavar F, Frontera OA, De Marinis F, Turna H, Lee JS, Ballinger M, Kowanetz M, He P, Chen DS, Sandler A and Gandara DR: Atezolizumab versus docetaxel in patients with previously treated non-small-cell lung cancer (OAK): a phase 3, open-label, multicentre randomised controlled trial. Lancet 389: 255-265, 2017.

2 Reck M, Rodriguez-Abreu D, Robinson AG, Hui R, Csoszi T, Fulop A, Gottfried M, Peled N, Tafreshi A, Cuffe S, O'Brien M, Rao S, Hotta K, Leiby MA, Lubiniecki GM, Shentu Y, Rangwala $\mathrm{R}$ and Brahmer JR: Pembrolizumab versus chemotherapy for PD-L1-positive non-small-cell lung cancer. N Engl J Med 375: 1823-1833, 2016.

3 Herbst RS, Baas P, Kim DW, Felip E, Perez-Gracia JL, Han JY, Molina J, Kim JH, Arvis CD, Ahn MJ, Majem M, Fidler MJ, de Castro G, Garrido M, Lubiniecki GM, Shentu Y, Im E, DolledFilhart $\mathrm{M}$ and Garon EB: Pembrolizumab versus docetaxel for previously treated, PD-L1-positive, advanced non-small-cell lung cancer (KEYNOTE-010): a randomised controlled trial. Lancet 387: 1540-1550, 2016.

4 Fehrenbacher L, Spira A, Ballinger M, Kowanetz M, Vansteenkiste J, Mazieres J, Park K, Smith D, Artal-Cortes A, Lewanski C, Braiteh F, Waterkamp D, He P, Zou W, Chen DS, Yi J, Sandler A, Rittmeyer A and Grp PS: Atezolizumab versus docetaxel for patients with previously treated non-small-cell lung cancer (POPLAR): A multicentre, open-label, phase 2 randomised controlled trial. Lancet 387: 1837-1846, 2016.

5 Brahmer J, Reckamp KL, Baas P, Crino L, Eberhardt WE, Poddubskaya E, Antonia S, Pluzanski A, Vokes EE, Holgado E, Waterhouse D, Ready N, Gainor J, Aren Frontera O, Havel L, Steins M, Garassino MC, Aerts JG, Domine M, Paz-Ares L, Reck M, Baudelet C, Harbison CT, Lestini B and Spigel DR: Nivolumab versus docetaxel in advanced squamous-cell nonsmall-cell lung cancer. N Engl J Med 373: 123-135, 2015.

6 Borghaei H, Paz-Ares L, Horn L, Spigel DR, Steins M, Ready NE, Chow LQ, Vokes EE, Felip E, Holgado E, Barlesi F, Kohlhaufl M, Arrieta O, Burgio MA, Fayette J, Lena H, Poddubskaya E, Gerber DE, Gettinger SN, Rudin CM, Rizvi N, Crino L, Blumenschein GR Jr., Antonia SJ, Dorange C, Harbison $\mathrm{CT}$, Graf Finckenstein $\mathrm{F}$ and Brahmer JR: Nivolumab versus docetaxel in advanced nonsquamous non-small-cell lung cancer. N Engl J Med 373: 1627-1639, 2015.

7 Shin DS, Zaretsky JM, Escuin-Ordinas H, Garcia-Diaz A, HuLieskovan S, Kalbasi A, Grasso CS, Hugo W, Sandoval S, Torrejon DY, Palaskas N, Rodriguez GA, Parisi G, Azhdam A, Chmielowski B, Cherry G, Seja E, Berent-Maoz B, Shintaku IP, Le DT, Pardoll DM, Diaz LA Jr., Tumeh PC, Graeber TG, Lo RS, Comin-Anduix B and Ribas A: Primary resistance to PD-1 blockade mediated by JAK1/2 mutations. Cancer Discov 7: 188201, 2017.

8 Marabelle A, Aspeslagh S, Postel-Vinay S and Soria JC: JAK mutations as escape mechanisms to anti-PD-1 therapy. Cancer Discov 7: 128-130, 2017. 
9 Koyama S, Akbay EA, Li YY, Herter-Sprie GS, Buczkowski KA, Richards WG, Gandhi L, Redig AJ, Rodig SJ, Asahina H, Jones RE, Kulkarni MM, Kuraguchi M, Palakurthi S, Fecci PE, Johnson BE, Janne PA, Engelman JA, Gangadharan SP, Costa DB, Freeman GJ, Bueno R, Hodi FS, Dranoff G, Wong KK and Hammerman PS: Adaptive resistance to therapeutic PD-1 blockade is associated with up-regulation of alternative immune checkpoints. Nat Commun 7: 10501, 2016.

10 Mellor A: Indoleamine 2,3 dioxygenase and regulation of $\mathrm{T}$ cell immunity. Biochem Biophys Res Commun 338: 20-24, 2005.

11 Della Chiesa M, Carlomagno S, Frumento G, Balsamo M, Cantoni C, Conte R, Moretta L, Moretta A and Vitale M: The tryptophan catabolite L-kynurenine inhibits the surface expression of NKp46-and NKG2D-activating receptors and regulates NK-cell function. Blood 108: 4118-4125, 2006.

12 Fallarino F, Grohmann U, You S, McGrath BC, Cavener DR, Vacca C, Orabona C, Bianchi R, Belladonna ML, Volpi C, Santamaria P, Fioretti MC and Puccetti P: The combined effects of tryptophan starvation and tryptophan catabolites downregulate $\mathrm{T}$ cell receptor zeta-chain and induce a regulatory phenotype in naive T cells. J Immunol 176: 6752-6761, 2006.

13 Powles T, Bellmunt J, Petrylak DP, Fong L, Nishiyama H, Sternberg CN, Chen M, Pang L, Munteanu M, Zhao Y and Smith DC: Pembrolizumab (pembro) plus epacadostat or placebo for locally advanced or metastatic urothelial carcinoma (UC) after failure of first-line platinum-containing chemotherapy: KEYNOTE698/ECHO-303. J Clin Oncol 36(suppl): abstr TPS4586, 2018.

14 Long GV, Dummer R, Hamid O, Gajewski T, Caglevic C, Dalle S, Arance A, Carlino MS, Grob JJ, Kim TM, Demidov LV, Robert C, Larkin JMG anderson J, Maleski JE, Jones MM, Diede SJ and Mitchell TC: Epacadostat (E) plus pembrolizumab (P) versus pembrolizumab alone in patients (pts) with unresectable or metastatic melanoma: Results of the phase 3 ECHO-301/KEYNOTE-252 study. J Clin Oncol 36(suppl): abstr $108,2018$.

15 Hui R, Munteanu M, Zhao Y, Luo Y, Samkari A and Garassino MC: ECHO-306/KEYNOTE-715: A phase 3 study of first-line epacadostat plus pembrolizumab with or without platinum-based chemotherapy vs pembrolizumab plus platinum-based chemotherapy plus placebo for metastatic non-small cell lung cancer (mNSCLC). J Clin Oncol 36(suppl): abstr TPS9104, 2018.

16 Cohen EEW, Rischin D, Pfister DG, Vermorken JB, Zhao Y, Gowda H, Ge JY, Jin F and Harrington KJ: A phase 3, randomized, open-label study of epacadostat plus pembrolizumab, pembrolizumab monotherapy and the EXTREME regimen as firstline treatment for recurrent/metastatic head and neck squamous cell carcinoma (R/M SCCHN): ECHO-304/KEYNOTE-669. J Clin Oncol 36(suppl): abstr TPS6090, 2018.

17 Balar AV, Plimack ER, Grivas P, Necchi A, Santis MD, Pang L, Keefe SM, O'Hayer K, Zhao Y and Wit RD: Phase 3, randomized, double-blind trial of pembrolizumab plus epacadostat or placebo for cisplatin-ineligible urothelial carcinoma (UC): KEYNOTE-672/ECHO-307. J Clin Oncol 36(suppl): abstr TPS4587, 2018.

18 Awad MM, Munteanu M, Zhao Y, Xu L, Samkari A and PazAres L: ECHO-305/KEYNOTE-654: A phase 3, randomized, double-blind study of first-line epacadostat plus pembrolizumab $v s$. pembrolizumab plus placebo for metastatic non-small cell lung cancer (mNSCLC) with high PD-L1 levels. J Clin Oncol 36(suppl): abstr TPS9109, 2018.
19 Zhai L, Spranger S, Binder DC, Gritsina G, Lauing KL, Giles FJ and Wainwright DA: Molecular pathways: Targeting IDO1 and other tryptophan dioxygenases for cancer immunotherapy. Clin Cancer Res 21: 5427-5433, 2015.

20 Kozuma Y, Takada K, Toyokawa G, Kohashi K, Shimokawa M, Hirai F, Tagawa $\mathrm{T}$, Okamoto $\mathrm{T}$, Oda $\mathrm{Y}$ and Maehara $\mathrm{Y}$ : Indoleamine 2,3-dioxygenase 1 and programmed cell deathligand 1 co-expression correlates with aggressive features in lung adenocarcinoma. Eur J Cancer 101: 20-29, 2018.

21 Toyokawa G, Takada K, Okamoto T, Shimokawa M, Kozuma Y, Matsubara T, Haratake N, Takamori S, Akamine T, Katsura M, Shoji F, Oda Y and Maehara Y: Computed tomography features of lung adenocarcinomas with programmed death ligand 1 expression. Clin Lung Cancer 18: e375-e383, 2017.

22 Takada K, Toyokawa G, Okamoto T, Baba S, Kozuma Y, Matsubara T, Haratake N, Akamine T, Takamori S, Katsura M, Shoji F, Honda H, Oda Y and Maehara Y: Metabolic characteristics of programmed cell death-ligand 1-expressing lung cancer on ${ }^{18} \mathrm{~F}$-fluorodeoxyglucose positron-emission tomography/computed tomography. Cancer Med 6: 2552-2561, 2017.

23 Goldstraw P, Crowley J, Chansky K, Giroux DJ, Groome PA, Rami-Porta R, Postmus PE, Rusch V and Sobin L: The IASLC Lung Cancer Staging Project: proposals for the revision of the TNM stage groupings in the forthcoming (seventh) edition of the TNM Classification of Malignant Tumours. J Thorac Oncol 2: 706-714, 2007.

24 Travis WD, Brambilla E, Nicholson AG, Yatabe Y, Austin JHM, Beasley MB, Chirieac LR, Dacic S, Duhig E, Flieder DB, Geisinger K, Hirsch FR, Ishikawa Y, Kerr KM, Noguchi M, Pelosi G, Powell CA, Tsao MS and Wistuba I: The 2015 World Health Organization Classification of Lung Tumors: Impact of genetic, clinical and radiologic advances since the 2004 classification. J Thorac Oncol 10: 1243-1260, 2015.

25 Kohno M, Okamoto T, Suda K, Shimokawa M, Kitahara H, Shimamatsu S, Konishi H, Yoshida T, Takenoyama M, Yano T and Maehara Y: Prognostic and therapeutic implications of aromatase expression in lung adenocarcinomas with EGFR mutations. Clin Cancer Res 20: 3613-3622, 2014.

26 Takada K, Okamoto T, Shoji F, Shimokawa M, Akamine T, Takamori S, Katsura M, Suzuki Y, Fujishita T, Toyokawa G, Morodomi Y, Okano S, Oda Y and Maehara Y: Clinical significance of PD-L1 Protein expression in surgically resected primary lung adenocarcinoma. J Thorac Oncol 11: 1879-1890, 2016.

27 Theate I, van Baren N, Pilotte L, Moulin P, Larrieu P, Renauld JC, Herve C, Gutierrez-Roelens I, Marbaix E, Sempoux C and Van den Eynde BJ: Extensive profiling of the expression of the indoleamine 2,3-dioxygenase 1 protein in normal and tumoral human tissues. Cancer Immunol Res 3: 161-172, 2015.

28 Toyokawa G, Takada K, Okamoto T, Kawanami S, Kozuma Y, Matsubara T, Haratake N, Takamori S, Akamine T, Katsura M, Yamada Y, Shoji F, Baba S, Kamitani T, Oda Y, Honda H and Maehara Y: Relevance between programmed death ligand 1 and radiologic invasiveness in pathologic stage I lung adenocarcinoma. Ann Thorac Surg 103: 1750-1757, 2017.

29 Kuriyama K, Seto M, Kasugai T, Higashiyama M, Kido S, Sawai Y, Kodama K and Kuroda C: Ground-glass opacity on thinsection CT: Value in differentiating subtypes of adenocarcinoma of the lung. Am J Roentgenol 173: 465-469, 1999. 
30 Suzuki K, Koike T, Asakawa T, Kusumoto M, Asamura H, Nagai K, Tada H, Mitsudomi T, Tsuboi M, Shibata T, Fukuda H and Kato H: A prospective radiological study of thin-section computed tomography to predict pathological noninvasiveness in peripheral clinical IA lung cancer (Japan Clinical Oncology Group 0201). J Thorac Oncol 6: 751-756, 2011

31 Rimm DL, Han G, Taube JM, Yi ES, Bridge JA, Flieder DB, Homer R, West WW, Wu H, Roden AC, Fujimoto J, Yu H anders R, Kowalewski A, Rivard C, Rehman J, Batenchuk C, Burns V, Hirsch FR and Wistuba II: A Prospective, Multi-institutional, pathologist-based assessment of 4 immunohistochemistry assays for PD-L1 expression in non-small cell lung cancer. JAMA Oncol 3: 1051-1058, 2017.

32 Ratcliffe MJ, Sharpe A, Midha A, Barker C, Scott M, Scorer P, Al-Masri H, Rebelatto MC and Walker J: Agreement between programmed cell death ligand-1 diagnostic assays across multiple protein expression cutoffs in non-small cell lung cancer. Clin Cancer Res 23: 3585-3591, 2017.
33 Hirsch FR, McElhinny A, Stanforth D, Ranger-Moore J, Jansson M, Kulangara K, Richardson W, Towne P, Hanks D, Vennapusa B, Mistry A, Kalamegham R, Averbuch S, Novotny J, Rubin E, Emancipator K, McCaffery I, Williams JA, Walker J, Longshore J, Tsao MS and Kerr KM: PD-L1 Immunohistochemistry assays for lung cancer: Results from phase 1 of the blueprint PD-L1 IHC assay comparison project. J Thorac Oncol 12: 208-222, 2017.

Received July 27, 2018

Revised August 5, 2018

Accepted August 7, 2018 